\title{
Evaluating Profitability of Shooting Star Candlestick Pattern in Indian Stock Market
}

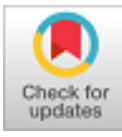

\author{
Sidharath Seth, Jaspal Singh
}

\begin{abstract}
This paper investigates the profitability of a candlestick reversal pattern 'Shooting Star' in Indian stock market. Its profitability is investigated by using daily data of Nifty 50 component stocks over the period from January 1, 2000 till December 31, 2017. Seven different trading strategies based on shooting star are tested using bootstrapped skewness adjusted t-test and binomial test. The superior performance of three trading strategies for one- and two-day holding periods demonstrates that it can be used to generate profits in Indian stock market. It is recommended that one should trade shooting stars of significantly smaller size and exit short positions within two days.

Index Terms: Technical Analysis, Shooting Star, Candlestick patterns, Indian Stock Market.
\end{abstract}

\section{INTRODUCTION}

Technical analysis makes use of historical price and volume figures to predict future direction of prices. It is one of the oldest techniques used to analyze the financial markets. It is widely followed by investing community (Smidt, 1965; Tayler and Allen, 1992; Billingsley and chance, 1996; Bankhofer and Hilbert, 1999). The findings of previous studies on the profitability of technical analysis have been mixed. Some of them have revealed the adverse performance of technical tools, as suggested by Levy (1971), Hofmann (1973), Malkiel (1996), Curcio et al. (1997), Mills (1997), Bessembinder and Chan (1998), Sullivan et al. (1999), Goldbaum (1999), Wang (2000), Day and Wang (2002), Dorfleitner and Klein (2002), Sullivan et al. (2003), Olson (2004) and Singh and Seth (2015, 2019), while others have strongly supported them for their superior returns, as reported by Treynor and Ferguson (1985), Sweeney (1986), Pruitt and White (1988), Lukac and Brorsen (1990), Brock et al. (1992), Blume et al. (1994), Balsara et al. (1996), Ito (1999), Ratner and Leal (1999), Lo et al. (2000), Detry and Gregoire (2001), Wong et al. (2003), Shen (2003), and Neely et al. (2012).

Dow Theory was believed to be the oldest as it dates to 1884 (Edwards and Magee, 1997). But after the publication of first book on candlestick by Steve Nison in 1991, it became evident that candlestick charting has even longer history as it was used in Japan by Munehisa homma in $18^{\text {th }}$ century to

Revised Manuscript Received on 30 July 2019.

* Correspondence Author

Dr. Sidharath Seth*, University School of Financial Studies, Guru Nanak Dev University, Amritsar, Punjab, India.

Dr. Jaspal Singh, University School of Financial Studies, Guru Nanak Dev University, Amritsar, Punjab, India.

(C) The Authors. Published by Blue Eyes Intelligence Engineering and Sciences Publication (BEIESP). This is an open access article under the CC-BY-NC-ND license http://creativecommons.org/licenses/by-nc-nd/4.0/ trade rice forward contracts (Nison, 1991). Candlestick charting makes use of patterns formed using open, high, low and close prices of a certain trading period to predict future price movements. This paper attempts to evaluate the profitability of a single candlestick pattern named 'Shooting Star'. The study is conducted using daily data of all the stocks comprising Nifty 50 index at National Stock Exchange, India from January 1, 2000 till December 31, 2017.

The rest of the paper is structured as follows: Section 2 reviews the past literature on candlesticks. Section 3 explains the data analyzed, candlestick charting and the methodology adopted. Section 4 deals with the discussion of the empirical results and finally, Section 5 concludes this paper.

\section{LITERATURE REVIEW}

Several studies have attempted to test the profitability of candlestick patterns on many financial markets. The first empirical work on candlesticks was done by Caginalp and Laurent (1998). They analyzed their performance on American markets and found that candlestick patterns have significant predictive value. Their findings were supported by Goo. et. al. (2007), Lu \& Shiu (2011), Lu et al. (2012), Lu \& Chen (2013), Lu (2014), Lu et. al. (2015) and Lu \& Shiu (2016), who confirmed that they were successful in generating significant positive returns for traders. On the contrary, the findings of Fock (2005), Marshall et. al (2006, 2008), Horton (2009) and Duvinage et al. (2013) showed that they failed in generating any superior returns.

Thus, the academic literature gives mixed results on the profitability of various candlestick patterns by focusing on various financial markets like American, Japanese, European and Taiwanese. Compared to previous empirical work, our study extends the research in various aspects. We focus comprehensively on single candlestick patterns i.e. Shooting Star, one of the most popular candlestick reversal patterns. The profitability is evaluated using distinct trading strategies over different holding time periods, spanning from one till ten days.

\section{DATA, CANDLESTICK AND RESEARCH METHODOLOGY}

\section{A. Candlestick charting}

A candlestick chart is constructed using open, high, low and closing price of the trading period, ranging from one minute to a decade, as shown in Fig. 1. However, it is more widely used on daily data. 
The opening and closing price are joined using a rectangular space called as body and its size depends upon the difference between the two prices. The color of the body is either white or black depending upon the relationship between opening and closing price. If opening price is higher than closing price, it is colored black (indicating bearishness) and if closing price is higher than opening price, it is colored white (indicting bullishness). The vertical lines above and below the body are called the shadows i.e. upper shadow and lower shadow, indicating the high and the low of the trading period.

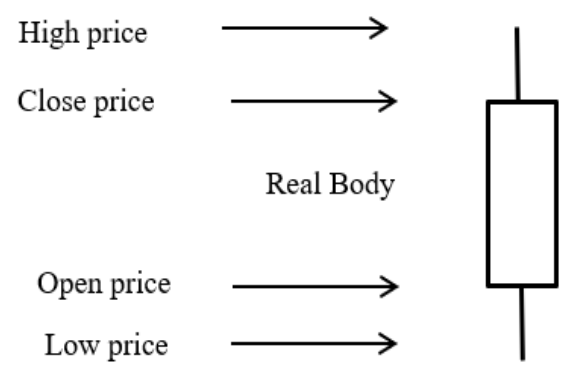

Fig.1 A white candlestick

The present study focusses on only one candlestick pattern i.e. Shooting Star. It is formed after an uptrend and indicates that the price had increased during the trading session but later fell as bears came to power. We follow Caginalp and Laurent (1998) criteria to identify the down trends which involves using the 3-day moving average for a total period of 6 days. The same has been adopted by Goo et al. (2007), Shiu and Lu (2011), Lu et al. (2012) and Lu and Chen (2013). A candlestick is considered depicting shooting star pattern, when it fulfills following three conditions as specified by Nison (1991) (Fig. 2).

1. The real body is at the lower end of the trading range. The color of the real body is not important.

2. A long upper shadow should be at least twice the height of the real body.

3. It should have no, or a very short, lower shadow.

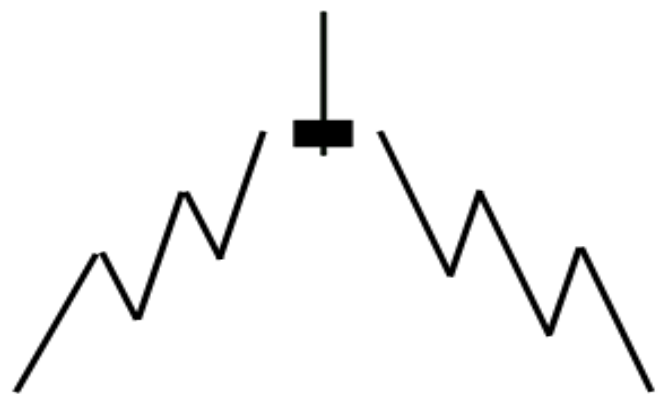

Fig. 2 A Shooting Star

The real body at the lower end of the trading range along with long upper shadow suggests that bulls, who were pushing the prices higher by creating demand pressure, from the beginning of the trading session, have lost their control to bears, who have commenced selling in the market. As a result, price may start falling.

\section{B. Research Methodology}

The profitability of the shooting star candlestick pattern is evaluated by assuming that a short position is made at the opening price on the day following the shooting star pattern

and held for one till ten days. The closing price of one till ten days is chosen as exit because all the previous studies have evaluated the profitability of candlestick patterns by holding them for one, three, five or ten days as suggested by Morris (1995) that candlestick analysis has value for the maximum period of ten days. Hence, we decided to determine profitability for all ten days and find the most profitable holding period. The profits are calculated by taking natural log of the closing price on the day of the exit divided by the opening price on the day following the shooting star pattern. Since it involves taking short position, if the log-return is negative, the pattern generates profits and vice-versa. Also, we employ five per cent stop loss rule as recommended by Goo et al. (2007) that it improves the profitability of the pattern. In addition to it, we employ another stop loss rule of exiting the trade at shooting star's high. The logic behind it is that price is continuing with uptrend and it has not led to trend reversal, so it is of no use to continue with short position. An attempt is made to focus on the relative size of the candlestick because large candles show huge price action, showing more fierce battle between bulls and bears. As a result, they may give better information and yield superior results. The candlestick size is determined by computing the proportion of trading range (i.e. difference between high and the low price of the day) with closing price. The performance of shooting stars having different size of at least five, ten, fifteen and twenty percent is determined separately. So, after considering above aspects, the profitability of shooting star is assessed using different trading strategies as briefed in table I.

\section{Table I: Details of all trading systems.}

\begin{tabular}{|c|c|}
\hline $\begin{array}{l}\text { Trading } \\
\text { Strateg }\end{array}$ & Particulars \\
\hline $\begin{array}{l}\mathbf{y} \\
1\end{array}$ & $\begin{array}{l}\text { Testing the profitability by holding for all ten days i.e. first } \\
\text { day till tenth day. }\end{array}$ \\
\hline 2 & $\begin{array}{l}\text { Testing the profitability by holding for all ten days i.e. first } \\
\text { day till tenth day with stop loss of five per cent as } \\
\text { suggested by Goo et al. (2007). }\end{array}$ \\
\hline 3 & $\begin{array}{l}\text { Testing the profitability by holding for all ten days i.e. first } \\
\text { day till tenth day with stop loss being shooting star's high. }\end{array}$ \\
\hline 4 & $\begin{array}{l}\text { Testing the profitability of only those shooting stars whose } \\
\text { trading range is at least five percent of the closing price, } \\
\text { by holding for all ten days i.e. first day till tenth day with } \\
\text { stop loss being shooting star's high. }\end{array}$ \\
\hline 5 & $\begin{array}{l}\text { Testing the profitability of only those shooting stars whose } \\
\text { trading range is at least ten percent of the closing price, by } \\
\text { holding for all ten days i.e. first day till tenth day with stop } \\
\text { loss being shooting star's high. }\end{array}$ \\
\hline 6 & $\begin{array}{l}\text { Testing the profitability of only those shooting stars whose } \\
\text { trading range is at least fifteen percent of the closing price, } \\
\text { by holding for all ten days i.e. first day till tenth day with } \\
\text { stop loss being shooting star's high. }\end{array}$ \\
\hline 7 & $\begin{array}{l}\text { Testing the profitability of only those shooting stars whose } \\
\text { trading range is at least twenty percent of the closing price, } \\
\text { by holding for all ten days i.e. first day till tenth day with } \\
\text { stop loss being shooting star's high. }\end{array}$ \\
\hline
\end{tabular}


To test the statistical significance of the profits generated by shooting star, bootstrapped skewness adjusted t-test is used as advocated by Lyon et al. (1999). The null hypothesis $\mathrm{H}_{0}$ : $\mu=0$ for the average return is used to test the statistical significance of profits earned upon the formation of candlestick pattern. If the average return is negative and null hypothesis is rejected, then the shooting star is successful in generating significant returns. Also, the binomial test is employed to test the null hypothesis $\mathrm{H}_{0}$ : $\mathrm{p}=0.5$ for the winning trades. It helps in testing whether the winning trades are as frequent as losing trades or not. If the ratio of winning rate of the trades is more than 0.5 and null hypothesis is rejected, then it shows that ratio of winning trades is superior over any random system.

\section{EMPIRICAL RESULTS}

Table II reports the profitability of shooting star on adopting trading strategy 1 . The results are mixed. The pattern generates significant superior returns and higher frequency of winning trades for one- and two-day holding period. Thereafter, its profitability starts dwindling. The pattern gives significant losses for five, six, seven, eight, nine- and ten-day holding periods. The frequency of winning trades becomes significantly poor for seven, eight, nine- and ten-day holding period. Among ten different holding periods, the one day holding period generates maximum return (mean return = $-0.202, \mathrm{p}<0.01$ ) along with highest frequency of winning trades (winning rate $=54.94 \%, \mathrm{p}<0.01$ ).

Table II: Results showing the profitability of shooting star pattern on adopting trading strategy 1

\begin{tabular}{|c|c|c|c|c|c|}
\hline $\begin{array}{l}\text { Holdin } \\
\text { g } \\
\text { Period }\end{array}$ & $\begin{array}{c}\text { No of } \\
\text { Pattern } \\
\text { s }\end{array}$ & $\begin{array}{r}\text { Averag } \\
\mathbf{e}\end{array}$ & Returns & $\begin{array}{r}\text { Winnin } \\
\mathbf{g}\end{array}$ & Rate \\
\hline 1 & 4589 & -0.202 & $\begin{array}{l}(<0.01) \\
*\end{array}$ & 54.94 & $\begin{array}{l}(<0.01) \\
*\end{array}$ \\
\hline 2 & 4589 & -0.156 & $\begin{array}{l}(<0.01) \\
*\end{array}$ & 53.29 & $\begin{array}{l}(<0.01) \\
*\end{array}$ \\
\hline 3 & 4589 & -0.075 & $(0.25)$ & 51.39 & $(0.06)$ \\
\hline 4 & 4589 & 0.056 & $(0.44)$ & 50.19 & $(0.8)$ \\
\hline 5 & 4589 & 0.195 & $(0.02)^{*}$ & 49.35 & $(0.38)$ \\
\hline 6 & 4589 & 0.276 & $\begin{array}{l}(<0.01) \\
*\end{array}$ & 49.19 & $(0.28)$ \\
\hline 7 & 4589 & 0.36 & $\begin{array}{l}(<0.01) \\
*\end{array}$ & 48.32 & $(0.02)^{*}$ \\
\hline 8 & 4589 & 0.371 & $\begin{array}{l}(<0.01) \\
*\end{array}$ & 47.45 & $\begin{array}{l}(<0.01) \\
*\end{array}$ \\
\hline 9 & 4589 & 0.425 & $\begin{array}{l}(<0.01) \\
*\end{array}$ & 46.58 & $\begin{array}{l}(<0.01) \\
*\end{array}$ \\
\hline 10 & 4589 & 0.455 & $\begin{array}{l}(<0.01) \\
*\end{array}$ & 46.58 & $\begin{array}{l}(<0.01) \\
*\end{array}$ \\
\hline
\end{tabular}

The table presents the average returns and winning rates for holding for one till ten days. The numbers in parentheses and brackets represent p-values of bootstrapped skewness adjusted t-test and binomial test. * indicates statistical significance at 5\% level.

Based on the findings of Goo et al. (2007) that the use of five per cent stop loss rule enhances the profitability of the trading strategy, we made an attempt to incorporate five per cent stop loss rule and see whether it improved the performance of shooting star pattern or not. The results obtained in table III indicate that the five per cent stop loss rule also provides mixed results but shows slight improvement in the performance. The pattern displays superior performance for one- and two-day holding period as their average return and frequency of winning trades is significantly better than any random system. The average loss is significant for six, seven, eight, nine- and ten-day holding periods. The frequency of winning trades is found to be significantly poor for six, seven, eight, nine- and ten-day holding periods. This leads to the conclusion that five per cent stop loss rule is recommended to be used with shooting star pattern in Indian stock market for one- and two-day holding periods only.

Table III: Results showing the profitability of shooting star pattern on adopting trading strategy 2

\begin{tabular}{|c|c|c|c|c|c|}
\hline $\begin{array}{c}\text { Holdin } \\
\text { g } \\
\text { Period } \\
\end{array}$ & $\begin{array}{c}\text { No of } \\
\text { Pattern } \\
\text { s }\end{array}$ & $\begin{array}{r}\text { Averag } \\
\mathbf{e}\end{array}$ & Returns & $\begin{array}{r}\text { Winnin } \\
\mathbf{g}\end{array}$ & Rate \\
\hline 1 & 4589 & -0.202 & $\begin{array}{l}(<0.01) \\
*\end{array}$ & 54.94 & $\begin{array}{l}(<0.01) \\
*\end{array}$ \\
\hline 2 & 4589 & -0.17 & $\begin{array}{l}(<0.01) \\
*\end{array}$ & 53.27 & $\begin{array}{l}(<0.01) \\
*\end{array}$ \\
\hline 3 & 4589 & -0.096 & -0.13 & 51.15 & -0.12 \\
\hline 4 & 4589 & 0.048 & -0.49 & 49.8 & -0.8 \\
\hline 5 & 4589 & 0.142 & -0.06 & 48.65 & -0.07 \\
\hline 6 & 4589 & 0.142 & $(0.01)^{*}$ & 47.99 & $\begin{array}{l}(<0.01) \\
*\end{array}$ \\
\hline 7 & 4589 & 0.232 & $(0.01)^{*}$ & 46.56 & $\begin{array}{l}(<0.01) \\
*\end{array}$ \\
\hline 8 & 4589 & 0.254 & $\begin{array}{l}(<0.01) \\
*\end{array}$ & 45.09 & $\begin{array}{l}(<0.01) \\
*\end{array}$ \\
\hline 9 & 4589 & 0.278 & $\begin{array}{l}(<0.01) \\
*\end{array}$ & 43.83 & $\begin{array}{l}(<0.01) \\
*\end{array}$ \\
\hline 10 & 4589 & 0.279 & $\begin{array}{l}(<0.01) \\
*\end{array}$ & 43.35 & $\begin{array}{l}(<0.01) \\
*\end{array}$ \\
\hline
\end{tabular}

The table presents the average returns and winning rates for holding for one till ten days. The numbers in parentheses and brackets represent $\mathrm{p}$-values of bootstrapped skewness adjusted t-test and binomial test. * indicates statistical significance at $5 \%$ level.

After the failure of above two strategies for holding periods beyond three days, another attempt was made to analyze the profitability of shooting star but with stop loss at it's high. It means that a short position made on the formation of shooting star is closed, if the price touches shooting star's high on any day from day one till ten. If the stop loss is not triggered, the position is held for all ten days. The logic behind exiting trading position at shooting star's high is that price is continuing with uptrend and trend reversal has not happened. Hence, it is not wise to continue holding short position and one should immediately exit with small loss. This strategy fails miserably. The results of the same are shown in Table IV. It is successful in delivering significant profits for only one day holding period, but it is lesser than previous trading strategies. For remaining holding periods, the performance is dismal as there are losses. The losses are significant for two, three, four, five, six, seven- and eight-day holding periods. There is a major drop in the winning rate. The frequency of winning trades is significantly poor for all the holding periods. 
Table IV: Results showing the profitability of shooting star pattern on adopting trading strategy 3

\begin{tabular}{|c|c|c|c|c|c|}
\hline $\begin{array}{l}\text { Holdin } \\
\text { g } \\
\text { Period }\end{array}$ & $\begin{array}{c}\text { No of } \\
\text { Pattern } \\
\text { s }\end{array}$ & $\begin{array}{r}\text { Averag } \\
\text { e }\end{array}$ & Returns & $\begin{array}{r}\text { Winnin } \\
\text { g }\end{array}$ & Rate \\
\hline 1 & 4390 & -0.136 & $\begin{array}{l}(<0.01) \\
*\end{array}$ & 45.65 & $\begin{array}{l}(<0.01) \\
*\end{array}$ \\
\hline 2 & 4390 & 0.333 & $\begin{array}{l}(<0.01) \\
*\end{array}$ & 34.78 & $\begin{array}{l}(<0.01) \\
*\end{array}$ \\
\hline 3 & 4390 & 0.226 & $\begin{array}{l}(<0.01) \\
*\end{array}$ & 33.64 & $\begin{array}{l}(<0.01) \\
*\end{array}$ \\
\hline 4 & 4390 & 0.229 & $\begin{array}{l}(<0.01) \\
*\end{array}$ & 31.57 & $\begin{array}{l}(<0.01) \\
*\end{array}$ \\
\hline 5 & 4390 & 0.23 & $\begin{array}{l}(<0.01) \\
*\end{array}$ & 29.7 & $\begin{array}{l}(<0.01) \\
*\end{array}$ \\
\hline 6 & 4390 & 0.208 & $\begin{array}{l}(<0.01) \\
*\end{array}$ & 28.99 & $\begin{array}{l}(<0.01) \\
*\end{array}$ \\
\hline 7 & 4390 & 0.158 & $(0.01)^{*}$ & 27.61 & $\begin{array}{l}(<0.01) \\
*\end{array}$ \\
\hline 8 & 4390 & 0.132 & $(0.05)^{*}$ & 26.08 & $\begin{array}{l}(<0.01) \\
*\end{array}$ \\
\hline 9 & 4390 & 0.129 & $(0.07)$ & 24.69 & $\begin{array}{l}(<0.01) \\
*\end{array}$ \\
\hline 10 & 4390 & 0.099 & $(0.17)$ & 24.19 & $\begin{array}{l}(<0.01) \\
*\end{array}$ \\
\hline
\end{tabular}

The table presents the average returns and winning rates for holding for one till ten days. The numbers in parentheses and brackets represent p-values of bootstrapped skewness adjusted t-test and binomial test. * indicates statistical significance at $5 \%$ level.

The trading strategies (as shown above) display that significant profits can be made on the formation of shooting star pattern for only one- and two-day holding periods. However, remaining holding periods fail to yield significant profits. Now, it becomes imperative to maximize the profits further and reduce losses on loosing trades. This is done by focusing on only those shooting star patterns which are larger in size. So, keeping the entry and exit criteria same, only those shooting stars, whose day's trading range is at least five percent of the closing price are now tested as shown in trading strategy 4 . The results of the same can be seen from table V. Only 716 shooting star patterns are found to qualify the above condition. It is found that it fails in generating significant profits for the traders. Rather, it results in loss for all the holding periods. Also, the frequency of winning trades is poor. Thus, larger patterns should be avoided.

Table V: Results showing the profitability of shooting star pattern on adopting trading strategy 4

\begin{tabular}{|c|c|c|c|c|c|}
\hline $\begin{array}{l}\text { Holdin } \\
\text { g } \\
\text { Period }\end{array}$ & $\begin{array}{c}\text { No of } \\
\text { Pattern } \\
\text { s }\end{array}$ & $\begin{array}{r}\text { Averag } \\
\text { e }\end{array}$ & Returns & $\begin{array}{r}\text { Winnin } \\
\mathbf{g}\end{array}$ & Rate \\
\hline 1 & 716 & 0.165 & $(0.14)$ & 42.32 & $\begin{array}{l}(<0.01) \\
*\end{array}$ \\
\hline 2 & 716 & 0.285 & $(0.04)^{*}$ & 47.21 & $(0.14)$ \\
\hline 3 & 716 & 0.185 & $(0.26)$ & 45.25 & $\begin{array}{l}(<0.01) \\
*\end{array}$ \\
\hline 4 & 716 & 0.368 & $(0.04)^{*}$ & 42.88 & $\begin{array}{l}(<0.01) \\
*\end{array}$ \\
\hline 5 & 716 & 0.451 & $(0.03)^{*}$ & 39.11 & $\begin{array}{l}(<0.01) \\
*\end{array}$ \\
\hline 6 & 716 & 0.472 & $(0.03)^{*}$ & 39.69 & $\begin{array}{l}(<0.01) \\
*\end{array}$ \\
\hline 7 & 716 & 0.392 & $(0.1)$ & 38.41 & $\begin{array}{l}(<0.01) \\
*\end{array}$ \\
\hline 8 & 716 & 0.392 & $(0.13)$ & 35.19 & $\begin{array}{l}(<0.01) \\
*\end{array}$ \\
\hline 9 & 716 & 0.498 & $(0.07)$ & 33.38 & $\begin{array}{l}(<0.01) \\
*\end{array}$ \\
\hline 10 & 716 & 0.492 & $(0.07)$ & 33.24 & $(<0.01)$ \\
\hline
\end{tabular}

The table presents the average returns and winning rates for holding for one till ten days. The numbers in parentheses and brackets represent p-values of bootstrapped skewness adjusted t-test and binomial test. * indicates statistical significance at 5\% level.

Table VI shows the result obtained on adopting trading strategy 5. This strategy involves trading only those shooting stars whose trading range is at least ten percent of the closing price. Like previous strategies, the trading position is held for all ten days i.e. first day till tenth day with stop loss being the shooting star's high. The number of shooting stars is reduced to 105 . The strategy fails to generate any significant profits. However, there is reduction in losses of one, three- and four-day holding periods. The winning rates have improved for all holding days over the previous strategy but are not good enough to beat any random trading system.

Table VI: Results showing the profitability of shooting star pattern on adopting trading strategy 5

\begin{tabular}{|c|c|c|c|c|c|}
\hline $\begin{array}{l}\text { Holdin } \\
\text { g } \\
\text { Period }\end{array}$ & $\begin{array}{c}\text { No of } \\
\text { Pattern } \\
\text { s }\end{array}$ & $\begin{array}{r}\text { Averag } \\
\text { e }\end{array}$ & Returns & $\begin{array}{r}\text { Winnin } \\
\text { g }\end{array}$ & Rate \\
\hline 1 & 105 & 0.113 & $(0.77)$ & 49.52 & $\begin{array}{l}(1.00 \\
)\end{array}$ \\
\hline 2 & 105 & 0.361 & $(0.40)$ & 51.43 & $\begin{array}{l}(0.84 \\
)\end{array}$ \\
\hline 3 & 105 & 0.026 & $(0.07)$ & 50.48 & $\begin{array}{l}(1.00 \\
)\end{array}$ \\
\hline 4 & 105 & 0.293 & $(0.60)$ & 47.62 & $\begin{array}{l}(0.69 \\
)\end{array}$ \\
\hline 5 & 105 & 0.611 & (0.31) & 45.71 & $\begin{array}{l}(0.43 \\
)\end{array}$ \\
\hline 6 & 105 & 0.729 & $(0.23)$ & 47.62 & $\begin{array}{l}(0.69 \\
)\end{array}$ \\
\hline 7 & 105 & 0.767 & $(0.23)$ & 47.62 & $\begin{array}{l}(0.69 \\
)\end{array}$ \\
\hline 8 & 105 & 0.642 & (0.37) & 46.67 & $\begin{array}{l}(0.56 \\
)\end{array}$ \\
\hline 9 & 105 & 0.759 & (0.33) & 43.81 & $\begin{array}{l}(0.24 \\
)\end{array}$ \\
\hline 10 & 105 & 0.755 & (0.33) & 40.95 & )$^{(0.08}$ \\
\hline
\end{tabular}

The table presents the average returns and winning rates for holding for one till ten days. The numbers in parentheses and brackets represent p-values of bootstrapped skewness adjusted t-test and binomial test. * indicates statistical significance at $5 \%$ level.

The result of trading strategy 6 is shown in table VII. This trading strategy involves making short position on only those shooting stars whose trading range is at least fifteen percent of the closing price. Only 46 shooting stars were found to satisfy this criterion. On holding the short position for all ten days i.e. first day till tenth day with stop loss being the shooting star's high, the pattern generates profits for two, three- and four-day holding periods, but it is not enough to generate significant profits. 
Table VII: Results showing the profitability of shooting star pattern on adopting trading strategy 6

\begin{tabular}{|c|c|c|c|c|c|}
\hline $\begin{array}{l}\text { Holdin } \\
\text { g } \\
\text { Period }\end{array}$ & $\begin{array}{c}\text { No of } \\
\text { Pattern } \\
\text { s }\end{array}$ & $\begin{array}{r}\text { Averag } \\
\mathbf{e}\end{array}$ & Returns & $\begin{array}{r}\text { Winnin } \\
\mathrm{g}\end{array}$ & Rate \\
\hline 1 & 46 & 0.321 & $(0.52)$ & 43.48 & $\begin{array}{l}(0.46 \\
)\end{array}$ \\
\hline 2 & 46 & -0.407 & $(0.54)$ & 58.69 & $\begin{array}{l}(0.30 \\
)\end{array}$ \\
\hline 3 & 46 & -0.905 & $(0.30)$ & 54.35 & $\begin{array}{l}(0.66 \\
)\end{array}$ \\
\hline 4 & 46 & -0.319 & $(0.73)$ & 54.35 & $\begin{array}{l}\text { (0.66 } \\
\text { ( }\end{array}$ \\
\hline 5 & 46 & 0.297 & $(0.72)$ & 47.83 & $\begin{array}{l}(0.88 \\
)\end{array}$ \\
\hline 6 & 46 & 0.313 & (0.69) & 52.17 & $\begin{array}{l}(0.88 \\
)\end{array}$ \\
\hline 7 & 46 & 0.561 & $(0.53)$ & 45.65 & $\begin{array}{l}(0.66 \\
)\end{array}$ \\
\hline 8 & 46 & 0.088 & $(0.94)$ & 50.00 & $\begin{array}{l}(1.00 \\
)\end{array}$ \\
\hline 9 & 46 & 0.362 & $(0.76)$ & 47.83 & $\begin{array}{l}(0.88 \\
)\end{array}$ \\
\hline 10 & 46 & 0.032 & (0.98) & 45.65 & $\begin{array}{l}(0.66 \\
)\end{array}$ \\
\hline
\end{tabular}

The table presents the average returns and winning rates for holding for one till ten days. The numbers in parentheses and brackets represent p-values of bootstrapped skewness adjusted t-test and binomial test. * indicates statistical significance at $5 \%$ level.

Table VIII reports the result of trading strategy 7, which involves trading in only those shooting stars whose trading range is at least twenty percent of the closing price. The profitability is tested by holding the trading position for all ten days i.e. first day till tenth day with stop loss being the shooting star's high. This strategy involves only 9 trades. It yields profits for one, two, eight, nine- and ten-day holding periods, but they are not statistically significant.

Table VIII: Results showing the profitability of shooting star pattern on adopting trading strategy 7

\begin{tabular}{|c|c|c|c|c|c|}
\hline $\begin{array}{l}\text { Holdin } \\
\text { g } \\
\text { Period }\end{array}$ & $\begin{array}{c}\text { No of } \\
\text { Pattern } \\
\text { s }\end{array}$ & $\begin{array}{r}\text { Averag } \\
\mathbf{e}\end{array}$ & Returns & $\begin{array}{r}\text { Winnin } \\
\mathbf{g}\end{array}$ & Rate \\
\hline 1 & 9 & -0.031 & $(0.90)$ & 44.44 & $\begin{array}{l}(1.00 \\
\end{array}$ \\
\hline 2 & 9 & -0.262 & $(0.97)$ & 44.44 & $\begin{array}{l}(1.00 \\
)\end{array}$ \\
\hline 3 & 9 & 0.648 & $(0.64)$ & 44.44 & $\begin{array}{l}(1.00 \\
\text { (1.00 }\end{array}$ \\
\hline 4 & 9 & 0.15 & $(0.97)$ & 44.44 & $\begin{array}{l}(1.00 \\
)\end{array}$ \\
\hline 5 & 9 & 0.803 & $(0.60)$ & 44.44 & $\begin{array}{l}(1.00 \\
)^{(1.00}\end{array}$ \\
\hline 6 & 9 & 1.383 & $(0.47)$ & 33.33 & $\begin{array}{l}(0.51 \\
)^{2}\end{array}$ \\
\hline 7 & 9 & 1.161 & (0.69) & 33.33 & $\begin{array}{l}(0.51 \\
)^{(0.51}\end{array}$ \\
\hline 8 & 9 & -0.488 & $(0.70)$ & 44.44 & $\begin{array}{l}(1.00 \\
{ }^{(1.00}\end{array}$ \\
\hline 9 & 9 & -0.298 & $(0.84)$ & 44.44 & $\begin{array}{l}(1.00 \\
)\end{array}$ \\
\hline 10 & 9 & -1.372 & $(0.58)$ & 55.56 & )$^{(1.00}$ \\
\hline
\end{tabular}

The table presents the average returns and winning rates for holding for one till ten days. The numbers in parentheses and brackets represent $\mathrm{p}$-values of bootstrapped skewness adjusted t-test and binomial test. * indicates statistical significance at 5\% level.

\section{CONCLUSION}

This study evaluates the profitability shooting star candlestick pattern by using daily data of Nifty 50 component stocks over the period from January 1, 2000 till December 31, 2017. The performance of seven different trading strategies based on shooting star are tested using bootstrapped skewness adjusted t-test and binomial test. The study shows that a trading position should not be blindly made on the formation of 'shooting star' pattern and exited on any day as it may lead to losses, which is consistent with the findings of Marshal et al. (2006, 2008) and Lu (2014). The recommendations on the basis of performance of different trading strategies, based on shooting star pattern are summarized below in table IX.

\section{Table IX: Recommendations based on performance of different trading strategies.}

\begin{tabular}{|c|c|c|}
\hline $\begin{array}{l}\text { Trading } \\
\text { Strateg } \\
\mathbf{y}\end{array}$ & Particulars & $\begin{array}{l}\text { Recommended } \\
\text { for trading or } \\
\text { not }\end{array}$ \\
\hline 1 & $\begin{array}{l}\text { Testing the profitability by } \\
\text { holding for all ten days i.e. first } \\
\text { day till tenth day. }\end{array}$ & $\begin{array}{l}\text { Recommended } \\
\text { for one- and } \\
\text { two-day } \\
\text { holding } \\
\text { periods. }\end{array}$ \\
\hline 2 & $\begin{array}{l}\text { Testing the profitability by } \\
\text { holding for all ten days i.e. first } \\
\text { day till tenth day with stop loss of } \\
\text { five per cent as suggested by Goo } \\
\text { et. al. (2007). }\end{array}$ & $\begin{array}{l}\text { Recommended } \\
\text { for one- and } \\
\text { two-day } \\
\text { holding } \\
\text { periods. }\end{array}$ \\
\hline 3 & $\begin{array}{l}\text { Testing the profitability by } \\
\text { holding for all ten days i.e. first } \\
\text { day till tenth day with stop loss } \\
\text { being shooting star's high. }\end{array}$ & $\begin{array}{l}\text { Recommended } \\
\text { for one day } \\
\text { holding period } \\
\text { only. }\end{array}$ \\
\hline 4 & $\begin{array}{l}\text { Testing the profitability of only } \\
\text { those shooting stars whose } \\
\text { trading range is at least five } \\
\text { percent of the closing price, by } \\
\text { holding for all ten days i.e. first } \\
\text { day till tenth day with stop loss } \\
\text { being shooting star's high. }\end{array}$ & $\begin{array}{r}\text { Not } \\
\text { Recommended }\end{array}$ \\
\hline 5 & $\begin{array}{l}\text { Testing the profitability of only } \\
\text { those shooting stars whose } \\
\text { trading range is at least ten } \\
\text { percent of the closing price, by } \\
\text { holding for all ten days i.e. first } \\
\text { day till tenth day with stop loss } \\
\text { being shooting star's high. }\end{array}$ & $\begin{array}{r}\text { Not } \\
\text { Recommended }\end{array}$ \\
\hline 6 & $\begin{array}{l}\text { Testing the profitability of only } \\
\text { those shooting stars whose } \\
\text { trading range is at least fifteen } \\
\text { percent of the closing price, by } \\
\text { holding for all ten days i.e. first } \\
\text { day till tenth day with stop loss } \\
\text { being shooting star's high. }\end{array}$ & $\begin{array}{r}\text { Not } \\
\text { Recommended }\end{array}$ \\
\hline 7 & $\begin{array}{l}\text { Testing the profitability of only } \\
\text { those shooting stars whose } \\
\text { trading range is at least twenty } \\
\text { percent of the closing price, by } \\
\text { holding for all ten days i.e. first } \\
\text { day till tenth day with stop loss } \\
\text { being shooting star's high. }\end{array}$ & $\begin{array}{r}\text { Not } \\
\text { Recommended }\end{array}$ \\
\hline
\end{tabular}


The superior performance of three trading strategies for oneand two-day holding periods demonstrates that it can be used to generate profits in Indian stock market. Our results support the findings of Caginalp and Laurent (1998), Goo et al. (2007), Lu et al. (2012), Lu and Chen (2013), Lu (2014), Lu et al. (2015) and Lu and Shiu (2016). It is recommended that one should trade shooting stars of significantly smaller size and exiting short positions within two days.

\section{ACKNOWLEDGEMENT}

The authors would like to thank ICSSR (Indian Council for Social Science Research) for funding this research work.

\section{References}

1. Bankhofer, U., \& Hilbert, A. (1999). Eine empirische Studie zur Anwendung mathematischer Methoden in der Versicherungspraxis. Zeitschrift für die gesamte Versicherungswissenschaft, 88(4), 611-643.

2. Billingsley, R. S., \& Chance, D. M. (1996). Benefits and limitations of diversification among commodity trading advisors. The Journal of Portfolio Management, 23(1), 65-80.

3. Caginalp, G., \& Laurent, H. (1998). The predictive power of price patterns. Applied Mathematical Finance, 5(3-4), 181-205.

4. Duvinage, M., Mazza, P., \& Petitjean, M. (2013). The intra-day performance of market timing strategies and trading systems based on Japanese candlesticks. Quantitative Finance, 13(7), 1059-1070.

5. Edwards, R. D., \& Magee, J. (1997). Technical Analysis of Stock Trends. Amacom, New York.

6. Fock, J. H., Klein, C., \& Zwergel, B. (2005). Performance of candlestick analysis on intraday futures data. The Journal of Derivatives, 13(1), 28-40.

7. Goo, Y. J., Chen, D. H., \& Chang, Y. W. (2007). The application of Japanese candlestick trading strategies in Taiwan. Investment Management \& Financial Innovations, 4(4), 49.

8. Horton, M. J. (2009). Stars, crows, and doji: The use of candlesticks in stock selection. The Quarterly Review of Economics and Finance, 49(2), 283-294.

9. Lu, T. H., \& Shiu, Y. M. (2011). Pinpoint and synergistic trading strategies of candlesticks. International Journal of Economics and Finance, 3(1), 234-244.

10. Lu, T. H., Shiu, Y. M., \& Liu, T. C. (2012). Profitable candlestick trading strategies-The evidence from a new perspective. Review of Financial Economics, 21(2), 63-68.

11. Lu, T. H., \& Chen, J. (2013). Candlestick charting in European stock markets. JASSA The Finsia Journal of applied Finance, (2), 20-25.

12. Lu, T. H. (2014). The profitability of candlestick charting in the Taiwan stock market. Pacific-Basin Finance Journal, 26, 65-78.

13. Lu, T. H., Chen, Y. C., \& Hsu, Y. C. (2015). Trend definition or holding strategy: What determines the profitability of candlestick charting?. Journal of Banking \& Finance, 61, 172-183.

14. Lu, T. H., \& Shiu, Y. M. (2016). Can 1-day candlestick patterns be profitable on the 30 component stocks of the DJIA?. Applied Economics, 1-10.

15. Lyon, J. D., Barber, B. M., \& Tsai, C. L. (1999). Improved methods for tests of long-run abnormal stock returns. The Journal of Finance, 54(1), 165-201.

16. Malkiel, B. G. (1999). A random walk down Wall Street: including a life-cycle guide to personal investing. WW Norton \& Company.

17. Marshall, B. R., Young, M. R., \& Rose, L. C. (2006). Candlestick technical trading strategies: can they create value for investors?. Journal of Banking \& Finance, 30(8), 2303-2323.

18. Marshall, B. R., Young, M. R., \& Cahan, R. (2008). Are candlestick technical trading strategies profitable in the Japanese equity market?. Review of Quantitative Finance and Accounting, 31(2), 191-207.

19. Morris, G. L. (1995). Candlestick Charting Explained: Timeless Techniques for Trading Stocks and Futures. McGraw Hill Professional, New York.

20. Nair, A. K. (1941). Distribution of Students't'and the Correlation Coefficient in Samples from Non-Normal Populations. Sankhyā: The Indian Journal of Statistics, 383-400.

21. Neyman, J., \& Pearson, E. S. (1928). On the use and interpretation of certain test criteria for purposes of statistical inference: Part I. Biometrika, 175-240.
22. Nison, S. (1991). Japanese candlestick charting techniques. New York Institute of Finance, New York.

23. Smidt, S. (1965). Amateur speculators: A survey of trading strategies, information sources and patterns of entry and exit from commodity futures markets by non-professional speculators. Cornell Studies in Policy and Administration, Cornell University.

24. Singh, J., \& Seth, S. (2015). Investigating Stock Market Indices of India - Empirical Analysis. Oxford Journal: An International Journal of Business \& Economics, 10(2), 29-40.

25. Singh, J. and Seth, S. (2015). Testing Performance of Public Sector Enterprises in India Using Carhart Four Factor Model: Empirical Analysis, The Journal of Institute of Public Enterprise, 38(3\&4), 1-11.

26. Singh, J. and Seth, S. (2016). S\&P BSE Sensex Vs CNX Nifty - Yield Comparison, Pacific Business Review International, 1(1), 155-162.

27. Singh, J. and Seth, S. (2018). Performance of Indian National Stock Exchange Indices : A Comparative Analysis, Finance India, 32(4), 1209-1226.

28. Singh, J. and Seth, S. (2019). Examining profitability of Hammer candlestick pattern in Indian Stock Market, RESEARCH REVIEW International Journal of Multidisciplinary, 4(1), 106-112.

29. "Sophister." (1928). Discussion of Small Samples Drawn from an Infinite Skew Population. Biometrika, 20A (3/4), 389-423.

30. Taylor, M. P., \& Allen, H. (1992). The use of technical analysis in the foreign exchange market. Journal of international Money and Finance, 11(3), 304-314

\section{AUTHORS PROFILE}

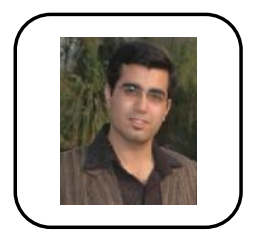

Dr. Sidharath Seth is a Post-Doctoral Scholar at University School of Financial Studies, Guru Nanak Dev University. Amritsar, Punjab, India. He has done Ph.D. on technical analysis and MBA with majors in finance. His area of specialization is capital markets. He has over 11 years of experience in stock market and research. He has published his research work in various international journals and presented papers in various international conferences. He is a sought after speaker on capital markets and has been a resource person in various workshops on capital markets.

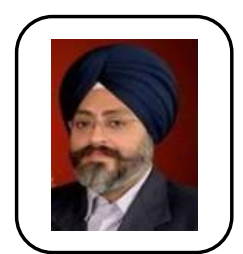

Dr.Jaspal Singh is Professor \& Head at University School of Financial Studies, Guru Nanak Dev University. Amritsar, Punjab, India. He specializes in the area of finance, investment management and taxation. He has done Ph.D. (Finance) and C.A (Inter). He has over 24 years of teaching experience in executive and post graduate programmes. Also, prior to starting his academic career, he has 6 years of Industry experience as Taxation \& Project consultant. He has to his credit more than 60 research papers published in various national and international journals of Emerald, Sage, Elsevier, Asian Research Consortium, CPI(USA), Inderscience, Euro Journals, Finance India etc. He has been awarded highly commended award 2012 by Emerald Literati Network. He has participated and presented papers in more than 29 conferences worldwide. His work was highly appreciated at Cambridge University, U.K in 2005 and University of Oxford in 2015. He was conferred with Top 50 Global Educators Award at a conference held at Oxford University, U.K. in 2015 for his work on Index investing. 